$\begin{array}{ll} & \text { Etnográfica } \\ \text { etnográfica } & \text { Revista do Centro em Rede de Investigação em }\end{array}$

Antropologia

vol. $14(3) \mid 2010$

Vol. $14(3)$

\title{
Introduction: consumption and its works
}

\section{Marta Vilar Rosales e Emília Margarida Marques}

\section{CpenEdition \\ Journals}

\section{Edição electrónica}

URL: https://journals.openedition.org/etnografica/188

DOI: 10.4000/etnografica.188

ISSN: 2182-2891

\section{Editora}

Centro em Rede de Investigação em Antropologia

\section{Edição impressa}

Data de publição: 1 outubro 2010

Paginação: 489-496

ISSN: 0873-6561

\section{Refêrencia eletrónica}

Marta Vilar Rosales e Emília Margarida Marques, «Introduction: consumption and its works»,

Etnográfica [Online], vol. 14 (3) | 2010, posto online no dia 03 outubro 2012, consultado o 10 fevereiro 2022. URL: http://journals.openedition.org/etnografica/188 ; DOI: https://doi.org/10.4000/etnografica. 188

\section{(@) $(1) \Theta$}

Etnográfica is licensed under a Creative Commons Attribution-NonCommercial 4.0 International License. 


\section{Introduction:}

\section{consumption and its works}

\section{Marta Vilar Rosales \\ and Emília Margarida Marques}

CRIA/FCSH-UNL (Portugal) and CRIA/ISCTE-IUL (Portugal)

THOUGH FAIRLY RECENT AS A RESEARCH TOPIC IN THE PORTUGUESE anthropology context, contemporary material culture and consumption practices have been intensely scrutinized since the 1980 s by all social sciences in many academic contexts, generating a plurality of debates that necessarily inspired and influenced the four papers presented in this collection. ${ }^{1}$ Despite this legacy, they however challenged us to reflect on a classical discussion that, even if always present in the field of contemporary material culture, did not gain primacy or much visibility in the empirical approaches to the field. Through their particular themes and specific approaches, and tough primarily focused on consumption practices, all four papers in this collection come across, and therefore make visible, instances of bridging, of encounter and of juxtaposition between consumption and what is sometimes identified as its opposite practice: work and production.

Portilho's consumers of organic food strongly value the sentiment of closeness they feel regarding the food producers from whom they directly buy in a street market - a proximity they contrast with the existing gap in conventional and large retail networks, and which enhances both their trust in food and their sense of behaving ethically as consumers. Consumption as a material and symbolic

1 This dossier gathers four articles resulting from papers on materiality and consumption presented at the last Luso-Afro-Brazilian Conference of Social Sciences (Braga, Portugal, February 2009). A remark on studies of material culture and consumption in the Portuguese anthropology context and a final comment on the papers complete the dossier. 
work of appropriation and (re)shaping of objects, spaces and meanings pervades Rosales' migrating subjects' accounts on their past and present homes, on their everyday routines and on themselves, therefore grounding her proposals on a much needed intersection between migration and material culture studies. The idea that work can be lived as leisure while consumption can be experienced as work pervades the diverse cooking practices and meanings differently lived and read by women and men in Barbosa's paper, once more stressing how fully consumption and work are framed by social context. Waged, formal work too makes its appearance, the material and symbolic resources it provides and the ways it is experienced unfolding into some meaningful consumption options by industrial women workers in Marques' article.

The complexity of the relationship between work (production) and consumption and the need to discuss it has been widely acknowledged (Carrier 2006; Carrier and Heyman 1997; Fine 2002; Foster 2008; Narotzky 2005; Miller 1987, 1995; Rothstein 2005; Slater 1997; Warde 1992), resulting in a considerable number of contributions that address the theme through diverse lenses and modalities. Contemporary debate is focused in a wide range of questions regarding the "often opaque connection" (Bridge and Smith 2003: 257 ) between the producers and the consumers of a specific commodity, or how the different stages (production, exchange and consumption) in the social life of things affect those same things, or yet how subjects deal with their multiple social roles (as workers and as consumers) and with their mutual influences and intersections. Even if the papers do not address all the topics mentioned and their multiple nuances, this does not cancel the fact that those topics need to be better explored. The following contributions have appeared to us as particularly useful to do it.

Marx's 1857 introduction to the Gründrisse (Marx 1973 [1857]) probably works as an apt starting point. In this essay, Marx sets out to investigate the relationship between production and consumption (as well as distribution and exchange) within the context of his intent to posit the fully social and historical character of the economic practice. Such sociological endeavour is obviously crucial to Marx's aim of understanding, criticizing and, ultimately, contributing to change capitalist economy and society. Therefore, any ascription of economic behaviours and institutions to (human) nature must, in his view, be discarded. Against the "individual and isolated hunter and fisherman, with whom Smith and Ricardo begin", Marx asserts: "Individuals producing in Society - hence socially determined individual production - is, of course, the point of departure" (Marx 1973 [1857]: 83). And the path he follows to emphatically establish the social character of production is to consider the diverse and integrated ways it interacts with consumption. Marx finds links of identity, mediation and mutual constitution between both spheres. Each is immediately the other, since while producing one is always consuming (skills, 
means of production, raw materials, etc...), and, conversely, "every kind of consumption $[\ldots]$ in one way or another produces human beings in some particular aspect" (Marx 1973 [1857]: 90-91). As for their mediating relationship, if, on the one hand, production provides consumption with its objects and if, moreover, it also provides the manner and the need for consumption ("The object of art - like every other product - creates a public which is sensitive to art and enjoys beauty", Marx exemplifies), consumption alone, on the other hand, "creates for the products the subject for whom they are products" (1973 [1857]: 91-92). Furthermore, this consuming subject must work to complete the works of production, for in a sense production alone cannot create the product: "the product, unlike a mere natural object, proves itself to be, becomes a product only through consumption" (1973 [1857]: 91, original emphasis). Thus each realm creates the other.

In Mary Douglas and Baron Isherwood's work on "the world of goods", economics is framed as a narrative against which to contrast a view of consumption that takes society and culture into account, and the relationship between production and consumption is once more brought to centre stage. "Is there any reason why consumption should be found at the end or at the beginning of a one way avenue?" (Douglas and Isherwood 1996 [1979]: 9). This sentence productively summarizes Douglas and Isherwood's reservations regarding the mainstream economic perspectives. Based on an artificial separation of the different economic spheres and on their abstraction from the broader social scheme, contemporary economics, according to the authors, tends to portray production, exchange and consumption as isolated and independent realms both from culture and from each other. On their quest to draw a response to this framework (which commences by enquiring "why people want goods"), the authors review a considerable number of significant economic perspectives on the relationship between production and consumption that either present consumption as an individualistic rational activity, or define it as the end or objective of all work, a "necessary evil" to consume whatever things. Douglas and Isherwood's main contribution to contemporary consumption studies suggests that all circulating goods serve as communication devices, i.e. as social and cultural fences and bridges between different people and between different groups. Therefore, and in order to discuss and depict the means by which they allow people to engage and communicate with each other, social theory ought start by restoring the unit that economic theory has shattered. This is a task for which anthropology has been contributing by analyzing the circular processes that, in the words of Douglas and Isherwood, are present in the ethnographic pictures that portray the "production of ancestors by means of ancestors" or the "production of cattle by means of cattle" (Douglas and Isherwood 1996 [1979]: 10). A theory of consumption has to be a theory of culture and a theory of social life. 
With a strong emphasis on power issues, culture and social life dwell at the core of Mintz's (1985) landmark research on the mutual shaping of production and consumption. Finding "odd" that anthropologists in contemporary food studies do not include production in their lines of inquiry, while the same topic is significantly present in studies of food in "preliterate societies", the author takes the production, trading, uses and meanings of a particular commodity (sugar) and its consumption to approach wholly anthropological questions of experience, meaning and power. According to Mintz, the massive adoption of sugar and related products by the English working class along the $19^{\text {th }}$ century could not be properly understood without a careful regard on matters such as production (the plantation system and the coerced labour that fuelled it), trade (struggles on protectionism vs. free trade), imperial administration and taxation of colonial commodities, and industrial work (the reproduction of the labour force, women's and child's labour, the re-shaping of daily schedules and of the experience of time). Cheapness, convenience and caloric density all favoured the "transformation of sugar from a preciosity into a daily commodity and into one of the first consumables fulfilling the capitalistic view of the relation between labor productivity and consumption" (Mintz 1985: 148): a view that highly esteemed the workers' consumption of any productivity-enhancing items. This does not imply, the author remarks, that "British working people were merely the passive witnesses of change" (1985: 181). Choices were obviously made and, moreover, meanings were built far beyond mere imitation, or emulation, of aristocratic or bourgeois sugar uses and significances. An efficient carrier of calories, sugar was also bestowed with a "high symbolic carrying power" (1985: 207) and this, too, has made its manifold success. Both choice and construction of meaning, however, take place within contexts over which no substantial choice is available to most individual subjects. Overwhelming "webs of signification" (Mintz borrows Geertz's phrase), "surpassing single lives in time and scale" (1985: 158) environ the subjects' symbolic work, obviously including the one done on consumption practices. Thus, there is neither precedence of consumption over production/work, nor the other way round. Mintz rather highlights the placement of both within "webs of signification" and of activity designed by the asymmetrical distribution of power among subjects and social groups.

In the introduction of The Social Life of Things, Appadurai (2003 [1986]) addresses the theme of contemporary production and consumption by means of three axes of discussion. The first results from his revision of the concept of commodity. Based on the classical works of Marx and Simmel, the concept acquires a broader definition, since it formally integrates all things intended for exchange, i.e. a situation that can characterize different things, in various stages of their social lives and in diverse exchange contexts. This perspective invites us, in the words of the author, not only to overcome the classical 
distinction between "capitalist" and "gift" societies, but also to focus on the things' whole trajectories, "from production, through exchange/distribution to consumption" (2003: 13). The second axis derives from the definition of demand as a function of various social practices and classifications. Consumption is, hence, eminently a relational activity, a "socially regulated and generated impulse" (2003: 32) whose main function is to send and receive social messages. This definition rests upon the assumption that demand integrates two types of relationship between production and consumption (demand is determined by social and economic forces, but, within limits, it can also manipulate them), a premise that allows for the stressing of their mutually constitutive nature, while promoting the conceptualization of demand as a complex social device of mediation between the different paths travelled by the commodities. The third axis emerges from the analysis of the knowledge inscribed in commodities. Complex and diverse, it integrates items that directly relate to their production (technical, social, aesthetic) and to their "appropriate" consumption. Even if these two forms of knowledge promote different readings and diverge from one another according to the distance separating producers and consumers, they somehow seem to have similar natures since both integrate specific technical, mythological and evaluative features. Once more, the idea that "the role of the commodities cannot [...] be divorced from questions of technology, production and trade" (2003: 35) is emphasised. Things have social "careers" (2003: 4l), i.e. significant biographies that necessarily have to be taken into account when one addresses them, even when concentrating in a particular stage of their lives.

The intersections between the spheres of work (and production) and consumption are evidenced and explored in all these contributions via the highlighting of their social and cultural dimensions. Both Marx (1973 [1857]) and Douglas and Isherwood (1996 [1979]), though departing from quite different theoretical perspectives, criticize the economics' views that abstract economic behaviours from the social and cultural fabric. Beyond the production and consumption of sugar, Mintz's (1985) work is mainly concerned with the interweaving of power and meaning. Finally, Appadurai (2003 [1986]) stresses how embedded in society and culture are not only demand, consumption practices and the knowledge activated in production and in consumption, but also things themselves and their trajectories.

By looking at people engaged in the daily practices which structure their lives and through which they relate to a multitude of social and material dimensions, the papers in this collection reinforce this overall view. Interestingly enough, the word "consumer" is conspicuously absent from the empirical descriptions (with the appropriate exception of Portilho's article) since the analytical lenses used mostly reveal social beings in their multisided contexts, relations and activities, rather than individuals playing a single role. 
Marta Rosales opens up the series, calling the attention to the potential of integrated approaches to materiality and migration. Her point of departure is the key role played by materiality, particularly home-related materiality (houses and the myriad objects they enclose) in migration experiences, as lived by the families she studied among migrants of Portuguese origin in several different contexts and situations. The remarkable extent to which the difficult, and even painful, work of home-(re)making escorts, mirrors and is indeed constitutive of the re-settling of one's life leads Rosales to elect domestic materiality as a realm of simultaneously expressive and constitutive consumption work, as well as a field where the complex encounter of "macro-contexts and micro-practices" that shapes migration processes might be fruitfully scrutinized. Bumping against too large furniture in a small house after losing her colonial elite residence due to the Portuguese decolonisation, a woman in Rosales' fieldwork clearly illustrates how acutely domestic things can materialize a social process and shape the way it is subjectively experienced.

Emília Margarida Marques makes the case for a full consideration of the links between work and consumption practices, against the theoretical narratives that assert the identitarian end of work, allegedly replaced by consumption as a self-building resource. After reviewing empirical researches on work experience as well as on some of the ways work and consumption interweave, she discusses her original material on women ex-workers in a suburban location near Lisbon, turned into an industrial locality by the late $60 \mathrm{~s}$ and the $70 \mathrm{~s}$ and de-industrializing nowadays. Highlighting those women's simultaneous and mutually reinforcing attitudes of subjective investment and lucid pragmatism towards work, as well as the explicit interlacing of their work (the wage it provides and the social condition it entails) and their consumption practices, Marques proposes to consider work as a pertinent frame for the working person as a consumer (to whom it provides chief material and symbolic resources) and consumption as a relevant arena for the material and symbolic value of work to be enacted.

Fátima Portilho addresses the relationship between the public and private spheres, asserting that it might be about to change due to the consumers' self-attribution of responsibility for the social and environmental impact of their consumption choices. Dismissing the idea of such an assignment of responsibility being an ideological move encouraged by companies and states in order to mitigate their own duties while simultaneously weakening public collective action, she argues that the consumers themselves are actively leading it. Based on her research among frequent customers in a Rio de Janeiro organic food street market, who state avoiding conventional political participation while expressing a firm belief in the power of consumers' options to effectively influence companies and governments, claiming personal authority over issues usually left to experts (health, nutrition, food safety) and attempting to materialize in their consumption practices some of their broader moral values and 
obligations, Portilho affirms the potential of consumption as a central form of political action.

Livia Barbosa mobilizes data from several differently designed researches she has conducted on food habits and on representations of the seven days of the week in Brazil to challenge the idea that the primordial links between food, social relations and sociability are being eroded by processes of modernization and individualization. Having identified a weekly emotional curve of positive and negative expectations regarding foreseen activities and feelings, Barbosa finds close and telling relations between the way food is materially and symbolically handled and the micro social dynamics at work in each occasion, from the hurried, low in sociability, rather frugal and monotonous weekdays breakfast to the long, food centred, emotionally dense Sunday lunch. From those and other researches, Barbosa additionally considers that Simmel's distinction between sociability and social relations is not useful in the Brazilian context, where the existential pleasures of social interaction always maintain autonomy regarding any other more pragmatic aims that might also shape every encounter.

So, what the contents of the four articles imply to us is that it is perhaps time to overcome the postmodernist practice of focusing on a particular fragment (Miller 2007) and try again to look for the consistency, logic and cosmology that brings together the overall aspects of peoples' lives. This means that it could make sense to discuss the relationships between people and contemporary material culture beyond the sphere of consumption (therefore not addressing it or production or mediation as separated fields of study), but also that there must be an effort to restore the unit between the economic, the social and the cultural realms. Asserting this standpoint requires finding an appropriate scale that allows the simultaneous emergency of the multiple aspects implied in practice, in general, and between work (and production) and consumption in particular, i.e., a specific site to observe and discuss the processes of appropriation, translation and domestication of the world. Extensively and intensively discussed in what concerns production and consumption practices observed through a separate and more or less restrictive understanding of both realms, contemporary approaches to materiality could benefit from a revision of their scopes and boundaries in order to promote a more integrative approach of the two fields of study. Following Miller's words (1995), it is by now evident that their separation in neither effective nor productive. This would be the perspective that would precisely allow us to depict and characterise the tasks of home decorating and managing described by Rosales as productive meaningful work, the materiality and meanings of clothes, make-up and industrial labour discussed in Marques's paper as objectively and subjectively intersecting, the encounters of consumers and producers of Portilho's fieldwork in Rio as key to the production of specific political standpoints and the making and consuming of shared meals studied by Barbosa as core moments of sociability. 
Two pieces of a different kind complete this dossier at both ends. Filomena Silvano describes and contextualizes some of the ways material culture and consumption have been looked at - or omitted - in the Portuguese anthropology context, from early approaches of rural technology and material culture to contemporary analyses of consumption. The dossier closes with a comment on the four articles by Daniel Miller, who kindly accepted our invitation to perform this task. We are grateful to them and to our colleagues Livia Barbosa and Fátima Portilho for their positive response and involvement in this process.

\section{REFERENCES}

APPADURAI, Arjun, 2003 [1986], "Introduction: commodities and the politics of value", in Arjun Appadurai (ed.), The Social Life of Things: Commodities in Cultural Perspective. Cambridge, Cambridge University Press.

BRIDGE, Gavin, and Adrian SMITH, 2003, "Intimate encounters: culture - economy - commodity", Society and Space, 21: 257-268.

CARRIER, James G., 2006, "The limits of culture: political economy and the anthropology of consumption", in Frank Trentmann (ed.), The Making of the Consumer: Knowledge, Power and Identity in the Modern World. Oxford, Berg, 271-289.

CARRIER, James G., and Josiah McC. HEYMAN, 1997, "Consumption and political economy", JRAY (n. s.), 3: 355-373.

DOUGLAS, Mary, and Baron ISHERWOOD, 1996 [1979], The World of Goods: Towards an Anthropology of Consumption. Harmondsworth, Penguin.

FINE, Ben, 2002, The World of Consumption. London, Routledge.

FOSTER, Robert, 2008, "Commodities, brands, love and kula: comparative notes on value creation, in honor of Nancy Munn”, Anthropological Theory, 8 (1): 9-25.

MARX, Karl, 1973 [1857], Grundrisse. Harmondsworth, Penguin.

MILlER, Daniel, 1987, Material Culture and Mass Consumption. Oxford, Blackwell.

—, 1995, "Consumption and commodities", Annual Review of Anthropology, 24: 141-161.

—, 2007, "Very big and very small societies", in António Pinto Ribeiro (ed.), The Urgency of Theory. Manchester, Carcanet, 79-105.

MINTZ, Sidney, 1985, Sweetness and Power: The Place of Sugar in Modern History. Harmondsworth, Penguin.

NAROTZKY, Susana, 2005, "Provisioning”, in James G. Carrier (ed.), A Handbook of Economic Anthropology. Cheltenham, Edward Elgar, 78-93.

ROTHSTEIN, Frances A., 2005, "Challenging consumption theory: production and consumption in Central Mexico", Critique of Anthropology, 25 (3): 27-306.

SLATER, Don, 1997, Consumer Culture and Modernity. Cambridge, Polity Press.

WARDE, Alan, 1992, "Notes on the relationship between production and consumption", in Roger Burrows and Catherine Marsh (eds.), Consumption and Class: Divisions and Change. London, MacMillan, 15-31. 